\title{
Wildfire promotes dominance of invasive giant reed (Arundo donax) in riparian ecosystems
}

\author{
Gretchen C. Coffman • Richard F. Ambrose • \\ Philip W. Rundel
}

Received: 26 June 2009/Accepted: 17 December 2009/Published online: 13 May 2010

(C) The Author(s) 2010. This article is published with open access at Springerlink.com

\begin{abstract}
Widespread invasion of riparian ecosystems by the large bamboo-like grass Arundo donax L. has altered community structure and ecological function of streams in California. This study evaluated the influence of wildfire on A. donax invasion by investigating its relative rate of reestablishment versus native riparian species after wildfire burned 300 ha of riparian woodlands along the Santa Clara River in southern California in October 2003. Postfire A. donax growth rates and productivity were compared to those of native woody riparian species in plots established before and after the fire. Arundo donax resprouted within days after the fire and exhibited higher growth rates and productivity compared to native riparian plants. Arundo donax grew 3-4 times faster than native woody riparian plants-up to a mean of $2.62 \mathrm{~cm} \mathrm{day}^{-1}$-and
\end{abstract}

G. C. Coffman - R. F. Ambrose

Department of Environmental Health Sciences, University

of California, Los Angeles, CA 90095-1772, USA

e-mail: rambrose@ucla.edu

G. C. Coffman ( $\bowtie)$

Marine Science Institute, University of California,

Santa Barbara, CA 93106-6150, USA

e-mail: coffman@msi.ucsb.edu

P. W. Rundel

Department of Ecology and Evolutionary Biology and Center for Embedded Networked Sensing, University of California, Los Angeles, CA 90095-1606, USA

e-mail: rundel@biology.ucla.edu reached up to $2.3 \mathrm{~m}$ in height less than 3 months after the fire. One year post-fire, A. donax density was nearly 20 times higher and productivity was 14-24 times higher than for native woody species. Three mechanisms-fire-adapted phenology, high growth rate, and growth response to nutrient enrichmentappear to promote the preemption of native woody riparian species by $A$. donax after fire. This greater dominance of $A$. donax after wildfire increased the susceptibility of riparian woodlands along the Santa Clara River to subsequent fire, potentially creating an invasive plant-fire regime cycle. Moreover, A. donax infestations appear to have allowed the wildfire to cross the broad bed of the Santa Clara River from the north, allowing thousands of acres of shrubland to the south to burn.

Keywords Arundo donax - Invasive plant-fire regime cycle $\cdot$ Invasive species $\cdot$ Mediterranean-type climate $\cdot$ Riparian $\cdot$ Wildfire

\section{Introduction}

Wildfire is a natural process in terrestrial ecosystems worldwide. Many ecosystems are adapted to fire as a periodic and natural disturbance regime, including Mediterranean-type shrublands, temperate conifer forests, savannas, and grasslands (Ellis 2000; Bond and Keeley 2005). In semi-arid climates, fire has a particularly significant role in shaping vegetation due 
to weather conditions favorable for growth and short periods in which decomposition can occur. Historically, dense cover of shrub biomass accumulating for up to 50 years or more provided fuel for high-intensity wildfires in shrublands of southern California and other semi-arid climate regions (Keeley et al. 1999; Keeley and Fotheringham 2001, 2005). Lightning was the primary natural cause of wildfires, especially during the dry, low humidity conditions that occur in late summer and fall (Naveh 1975; Keeley 1982; Keeley et al. 1999). Currently, most wildfires in these areas are anthropogenic in origin and occur much more frequently than they did historically when human population density was lower (D'Antonio and Vitousek 1992; Keeley et al. 1999).

Invasion of annual grass species has been linked to altered fire regimes in rangelands, deserts, and wildlands in many parts of the world (Brooks and Pyke 2001; Brooks et al. 2004; Sugihara et al. 2006). Invasive grass-fire cycles, also called invasive plantfire regime cycles, may ensue when alien grass species colonize an area and provide fuel for fire propagation, thereby increasing the frequency, extent, and intensity of fires (D'Antonio and Vitousek 1992; D'Antonio 2000; Brooks 2002; Brooks et al. 2004; Keeley 2004; Keeley and Fotheringham 2005). Rapid recovery of alien grass species after fire compared to native species after fire leads to increased susceptibility of that ecosystem to fire.

Large riparian corridors have historically acted as natural firebreaks in semi-arid Mediterranean-type climates (Dudley 1998; Dudley et al. 2000; Rundel 2000) because of their low-lying topography and relative absence of flammable fuels. However, invasive woody species have been shown to alter this situation. Thickets of saltcedar (Tamarix ramosissima), for example, have invaded riverine corridors throughout the Southwestern United States. Saltcedar burns more frequently and destructively than native riparian vegetation (Dudley et al. 2000) and resprouts rapidly from the rootcrown the year after it is burned (Duncan 1997).

In coastal shrubland watersheds of California, a large invasive grass species Arundo donax L. (often called giant reed and hereafter referred to as Arundo) poses multiple threats in riparian ecosystems, with many similarities to saltcedar, including high flammability. Arundo was introduced from southern Eurasia into California several hundred years ago for erosion control and building materials (Robbins et al. 1951; Perdue 1958). It now infests many stream and river systems throughout coastal California (Gaffney 2002) and other arid and Mediterraneantype climates worldwide, including South Africa, Australia, and the Mediterranean Basin. The natural flood disturbance regime in these climates successfully distributes vegetative culms and rhizomes of Arundo along streams, where it establishes readily on bare substrates (Else 1996). Studies indicate that increased water and nutrient delivery to these systems has increased its invasion success (Coffman 2007), yet the influence of fire on its invasion in river systems remains relatively unexplored. Several accounts suggest that infestations of Arundo have increased fuel load as well as fire frequency and intensity along riparian corridors (Robbins et al. 1951; Bell 1997; Scott 1994; D’Antonio 2000).

The Simi/Verdale wildfire of October 2003 (Keeley and Fotheringham 2005) provided the opportunity to study the role of fire in the invasion of riparian terrace ecosystems of the Santa Clara River by Arundo after hundreds of hectares of healthy riparian ecosystems containing a mixture of native riparian vegetation and Arundo burned. In this study, we compared growth and recolonization of Arundo to that of native plant species in this riparian ecosystem after the wildfire. We hypothesized that Arundo's immediate post-fire resprouting, phenology, and higher growth rate compared to native plants and the high soil nutrient content after fire would promote the dominance of Arundo.

\section{Methods}

\section{Study area}

The Simi/Verdale fire burned more than 45,000 ha of shrublands, grasslands, and riparian ecosystems from 25 October to 1 November 2003 (Keeley and Fotheringham 2005; Coffman 2007; California Department of Forestry and Fire Protection unpublished data; G. Coffman unpublished data; Fig. 1). Fire severity was variable throughout the riparian areas burned, but was predominately high or deep burning in areas in which Arundo density was highest. Study sites were located along the Santa Clara River floodplain throughout approximately 300 ha of riparian ecosystems burned in this fire. 
Percent canopy closure was variable throughout sites before the fire-from 10 to $45 \%$ cover of trees and shrubs. We observed deep burning (high fire severity) in study sites with a few patches of moderate fire severity on the edges of a couple of the sites according to field indicators described in Keeley (2009). Indicators observed throughout study sites included: native riparian trees in the canopy layer killed; all leaves consumed; shrubs burned to ground or only skeletons remaining; surface litter of all sizes consumed; and white ash deposition and charred organic matter between 1 and $30 \mathrm{~cm}$ thick. Most native trees and shrubs were top-killed with no green or singed leaves remaining. Some woody native plants resprouted from stumps and others did not. According to the County of Ventura, Fire Department records, no other recorded fires from 1918 to present (greater than 1 acre) were found to coincide with our 14 study sites within the 500-year floodplain of the Santa Clara River. Detailed descriptions of fire intensity and stand composition are available from the author.

Natural riparian vegetation along the river consisted of large black cottonwood (Populus balsamifera subsp. trichocarpa), Fremont cottonwood
(Populus fremontii), and red willow (Salix laevigata) trees in the canopy layer. A mixture of smaller trees and shrubs comprised the understory layer, including arroyo willow (Salix lasiolepis), sandbar willow (Salix exigua), shining willow (Salix lucida subsp. lasiandra), mulefat (Baccharis salicifolia), and blue elderberry (Sambucus mexicana). Species names follow Hickman (1993). Currently, Arundo infests more than 2,000 ha of floodplain along the Santa Clara River (Stillwater Sciences, URS 2007).

\section{Study species}

Arundo is a robust, perennial, bamboo-like member of the Poaceae family that has become widely established throughout the floodplains and terraces of rivers and streams in California and other warm, temperate climates worldwide (Hickman 1993). Arundo reproduces vegetatively through a network of large rhizomes that grow horizontally just below the soil surface. Under some conditions it produces a large (3-6 dm), terminal, plume-like inflorescence (panicle) at the end of the growing season (Hickman 1993); however, seeds of the inflorescence are generally sterile in California (Johnson et al. 2006).

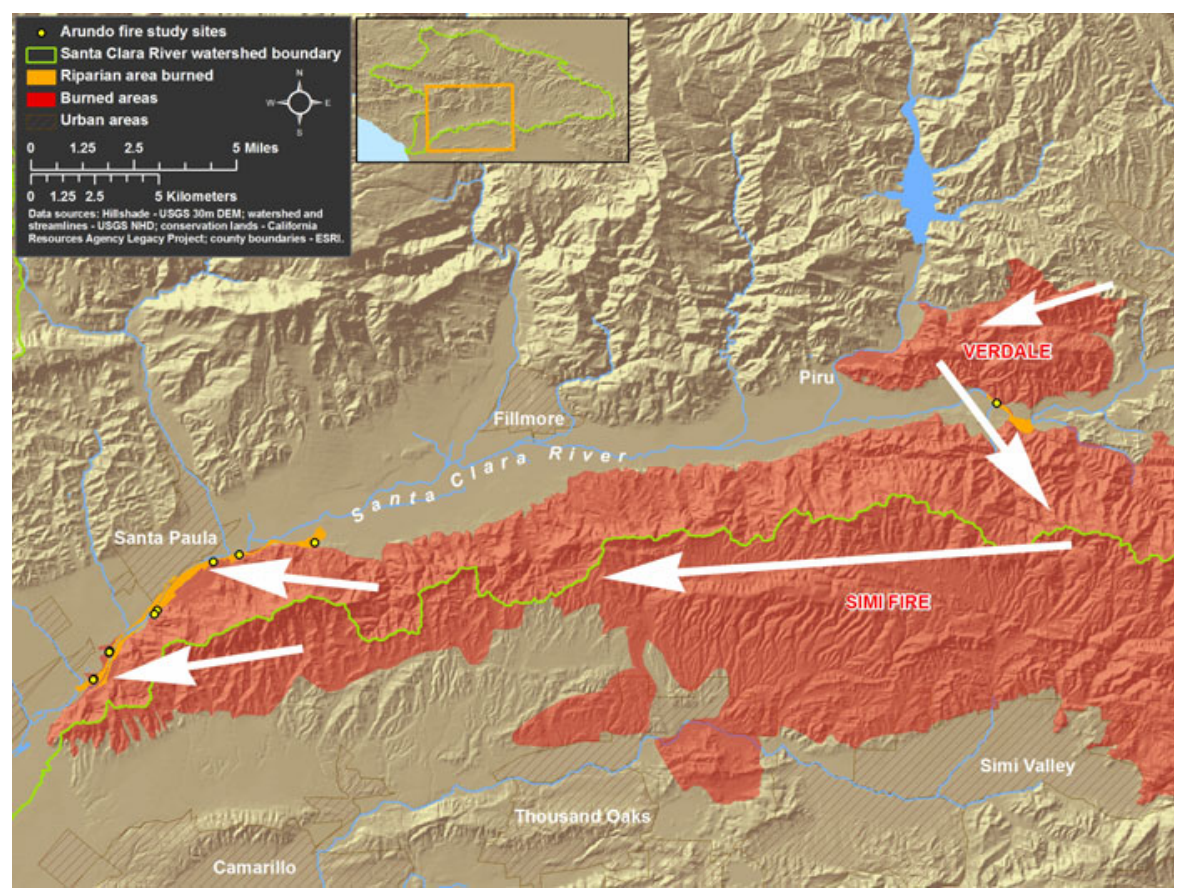

Fig. 1 Location of study sites within riparian ecosystems along the Santa Clara River, Ventura County, California. Arrows indicate progression of the Simi/Verdale wildfire 
For comparison, we also studied several native woody riparian plant species commonly found on burned riparian terraces and along other rivers in southern California, including Salix laevigata, S. lasiolepis, S. exigua, Populus balsamifera subsp. trichocarpa, and Baccharis salicifolia.

Sampling design and methods

Six permanent study sites established in a previous study (Coffman 2007) along the Santa Clara River burned during the 2003 wildfire; all were located on riparian floodplain terraces adjacent to shrubland ecosystems (Fig. 1). We compared pre-fire plant composition and soil nutrient data collected in summer 2003 at these six permanent monitoring sites to data collected monthly during 2004, the year after the wildfire occurred. We established eight additional study sites along riparian terrace areas burned to the west of the permanent study sites to ensure that sites were well-distributed throughout the burned areas and represented the range of environmental conditions found in the study area. We monitored reestablishment of plant cover on the 14 sites from November 2003 to December 2004. Each study site was approximately $600 \mathrm{~m}^{2}$ and $30 \times 20 \mathrm{~m}$ in extent.
Precipitation and temperature data along the Santa Clara River were recorded at the Piru 2 ESE station $\left(34.40^{\circ} \mathrm{N} 118.75^{\circ} \mathrm{W}\right.$, elevation $\left.222 \mathrm{~m}\right)$. Although $24 \mathrm{~mm}$ of rain were recorded only 5 days after the fire, the 2003-2004 hydrologic year was relatively dry with a total of $256 \mathrm{~mm}$ compared to a long-term mean of about $435 \mathrm{~mm}$ (Fig. 2).

We determined change in plant abundance in burned areas by comparing pre- and post-fire (summer 2003 and July 2004) percent cover of Arundo and native woody plant species in the six permanent study sites. Plant composition before the fire was determined by ocular estimation of percent aerial cover within the entire study site area. Since all trees and shrubs were top-burned, we used visual estimates of percent aerial cover of new seedlings and stump resprouts by species within $1 \mathrm{~m}^{2}$ quadrants placed randomly throughout all study sites during post-fire sampling periods and within six study sites during summer 2003. Post-fire mean shoot density (stems $\mathrm{m}^{-2}$ ) of Arundo and all native species were sampled monthly (March to September 2004) within six $1 \mathrm{~m}^{2}$ quadrants (placed randomly each sampling period) within all 14 study sites. We measured mean shoot length $(\mathrm{cm})$ and basal diameter $(\mathrm{mm})$ of 20 randomly selected individuals of
Fig. 2 Mean monthly precipitation and temperature within the Santa Clara River study area near Piru, CA for the study period (October 2003-December 2004). Frost label indicates freezing air temperatures (from 0 to $-5^{\circ} \mathrm{C}$ ) were experienced near the ground surface at several of the low-lying sites for several days

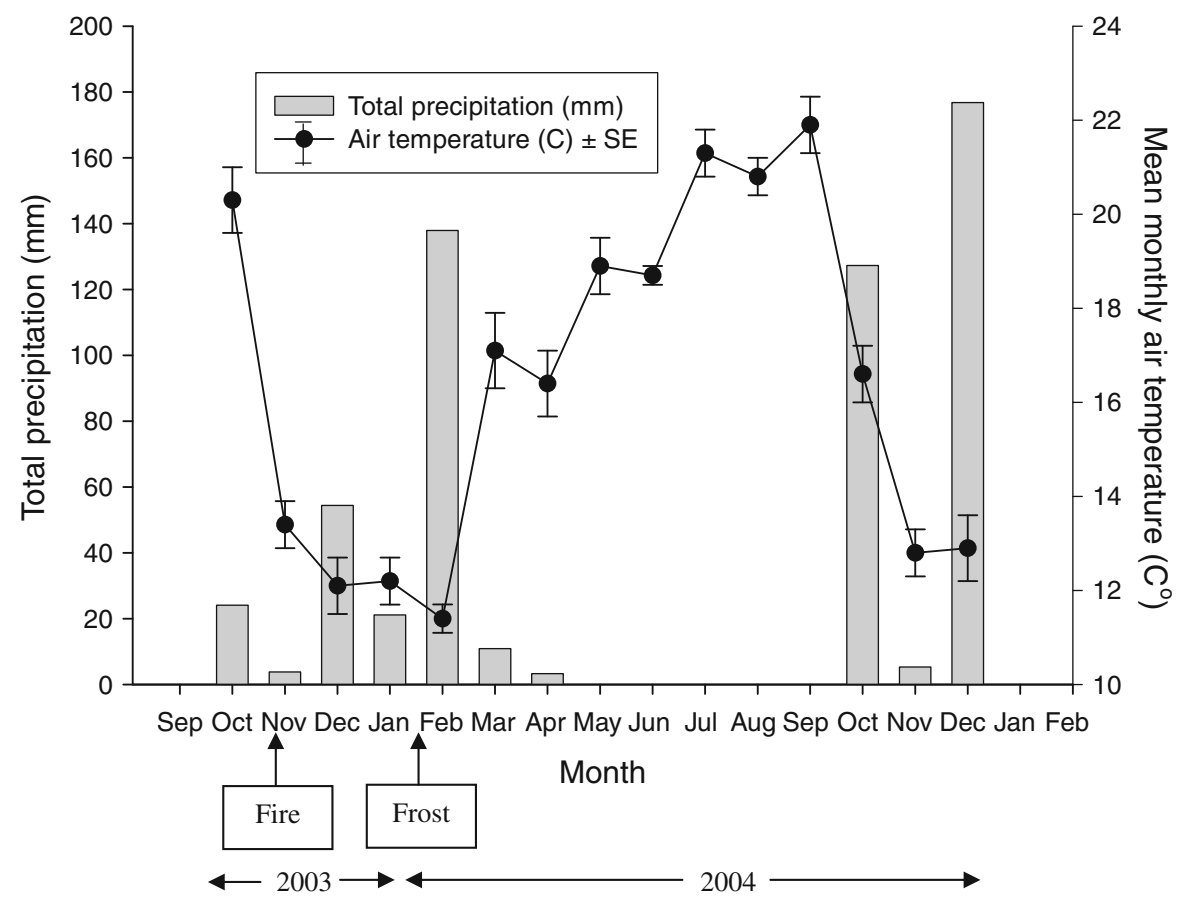


Arundo and each dominant native woody riparian species at all sites during each post-fire sampling period. In addition, we measured shoot height and basal diameter $(10 \mathrm{~cm}$ above the soil surface) of three permanently marked Arundo and native plant shoots (three of each species) during each sampling period. We calculated mean shoot elongation rate $\left(\mathrm{cm} \mathrm{day}{ }^{-1}\right)$ for each species using data from permanently marked individuals.

We calculated the aboveground biomass, relative growth rates (RGRs), and productivity of plants within the study sites using plant dimension data collected during the study period. Non-destructive dimensional analyses were used to estimate aboveground biomass dry weight of plants in study sites with minimal plant growth interference (Whittaker 1965; Whittaker and Marks 1975; Sharifi et al. 1982; Spencer et al. 2006). We created regression models for each species using basal diameter, shoot length, and aboveground biomass of culm/branch samples measured in a nearby field experiment to predict biomass of each individual plant sampled in the study sites. Regression models were based on Arundo (resprouts) and native woody plants (resprouts) grown at an experimental field plot on a terrace of the Santa Clara River near the burned study sites. Regression models for aboveground biomass were very highly significant for all species $\left(r^{2}=0.971-\right.$ 0.990, $P<0.001$; Coffman, 2007). Biomass of Arundo and native species was estimated based on both basal diameter and shoot length measurements taken at all study sites. All data were log transformed in regression models to achieve normally distributed residuals.

We calculated RGRs for all permanently marked individuals using the following differential equation, where $W$ is the total aboveground biomass dry weight ( $\mathrm{g}$ ) of each shoot, $t$ is time (days post-fire), and $\ln$ is natural logarithm:

$\mathrm{RGR}=\frac{\mathrm{d} W}{\mathrm{~d} t} \frac{1}{W}=\frac{\mathrm{d}(\ln W)}{\mathrm{d} t}$.

Mean productivity $\left(\mathrm{kg} \mathrm{m}^{-2}\right.$ year $^{-1}$ ) for each species was calculated at approximately 1 year post-fire. We estimated biomass $(\mathrm{kg})$ for the 20 randomly sampled culms/stems for each species measured during September 2004. For each species, mean biomass per shoot $\left(\mathrm{kg}\right.$ shoot $\left.^{-1}\right)$ was multiplied by mean density (shoots $\mathrm{m}^{-2}$ ) at each study site and then divided by time (1 year). We averaged productivity calculations for each species across study sites.

Five soil sub-samples were collected at each study site adjacent to Arundo and each native woody plant species in summer 2003 (Arundo and S. laevigata only) and immediately after the fire. Samples were collected in the upper $20 \mathrm{~cm}$ of the soil where nutrient concentrations are greatest. For each species, five soil samples were combined into a composite sample by thorough mixing in a stainless steel bowl. Soil samples were air-dried and ground to a powder in preparation for nutrient content analyses at the DANR Analytical Laboratory in Davis, California using standard techniques for total nitrogen (total $\mathrm{N}-\%)$, nitrate- $\mathrm{N}\left(\mathrm{NO}_{3}-\mathrm{N}-\mathrm{ppm}\right)$, ammonia- $\mathrm{N}\left(\mathrm{NH}_{4}-\right.$ $\mathrm{N}-\mathrm{ppm})$, and orthophosphate $\left(\mathrm{PO}_{4}-\mathrm{P}-\mathrm{ppm}\right.$; http:// danranlab.ucanr.org/). Soil grain size was analyzed at UCLA with a hydrometer to determine the particle size distribution of sand, silt, and clay in soil suspension (Sheldrick and Wang 1993).

\section{Statistical analyses}

One-way and two-way analysis of variance (ANOVA) tests were used to analyze effects of various combinations of factors (plant type and time) on plant performance and growth data (dependent or response variables; Systat Software, Inc 2000). We conducted a one-way ANOVA of productivity $\left(\mathrm{kg} \mathrm{m}^{-2}\right.$ year $^{-1}$ ) by species (Arundo, B. salicifolia, and $S$. laevigata). Two-way ANOVAs for plant performance metrics by factors of plant type (Arundo and native plant species) and time (pre-fire vs. postfire or months post-fire) were conducted to determine differences in plant growth by species over time postfire. Dependent variables included plant abundance (percent cover), density (stem $\mathrm{m}^{-2}$ ), shoot length (cm), and soil nutrient concentrations $\left(\mathrm{NH}_{4}-\mathrm{N}, \mathrm{NO}_{3}{ }^{-}\right.$ $\mathrm{N}$, and $\mathrm{PO}_{4}-\mathrm{P}$ in ppm). Soil grain size (\% silt + clay) was used as a covariate in two-way ANOVAs for soil nutrients. Repeated measures ANOVA were used for shoot elongation rate $\left(\mathrm{cm} \mathrm{day}^{-1}\right)$ and RGR $\left(\mathrm{g} \mathrm{g}^{-1}\right.$ day $\left.^{-1}\right)$ because data consisted of repeated samplings of the same individuals over time.

Tukey's post-hoc test was used for pairwise comparisons of means in one-way ANOVAs. We performed ANOVA $F$-tests to evaluate a priori contrasts between means of grouping variables and levels in two-way and repeated measures ANOVA 
results. Probability plots were examined to test for normality of data and to identify any data that required transformation. All biomass, soil $\mathrm{NH}_{4}-\mathrm{N}$, and soil $\mathrm{NO}_{3}-\mathrm{N}$ data were $\ln$ transformed. When means and standard errors are used to describe or present statistical differences, data were back-transformed and reported in original units.

\section{Results}

The pre-fire diameter of native woody riparian species varied by species as follows: B. salicifolia $(1-4 \mathrm{~cm})$, Salix exigua $(2-5 \mathrm{~cm}), \quad S$. lasiolepis $(9-22 \mathrm{~cm})$, S. laevigata $(62-75 \mathrm{~cm}), P$. balsamifera subsp. trichocarpa (21-70), and $P$. fremontii $(72-80 \mathrm{~cm})$. Regeneration of native plant species observed in study sites was predominantly by new seedlings. Resprouting from the root crown was only observed at a few sites for the following species (range of diameters): P. balsamifera subsp. trichocarpa (1-2 cm, died by the end of summer 2003), B. salicifolia $(1-2 \mathrm{~cm}), \quad S$. lasiolepis $(3-14 \mathrm{~cm})$, S. exigua $(2-5 \mathrm{~cm})$, and $S$. laevigata $(7-12 \mathrm{~cm})$.

Pre- versus post-fire plant abundance

Percent cover of Arundo was significantly greater than native woody riparian plant cover both before and after the study sites were burned (Table 1). Although both Arundo $(65.0 \pm 6.7 \%$ cover, mean $\pm \mathrm{SE})$ and the native woody plants $(21.7 \pm 6.0 \%$ cover $)$ were more abundant before the fire than after, less than a year after the fire Arundo $(42.8 \pm 4.3 \%$ cover $)$ was the overwhelmingly dominant plant species in these riparian ecosystems (native woody species $=0.4 \pm 0.2 \%$ cover). Thus, native woody species comprised $25.0 \%$ relative cover of the total vegetation before the fire and less than $1 \%$ of the vegetation in burned riparian terraces 9 months after the fire.

Post-fire density

The two-way ANOVA (plant type $\mathrm{x}$ time period) of plant density revealed a significant two-way interaction (Table 1). The mean density of Arundo (stems $\mathrm{m}^{-2}$ ) was significantly greater than that of native plant species for all months sampled (March-September 2004; Fig. 3a). Mean density of native plant species declined somewhat over time during the first year after the fire, although differences between sampling periods were not significant. However, mean density of Arundo shoots increased significantly over time. A year after the wildfire, Arundo density $\left(26.3 \pm 3.2\right.$ stems $\left.\mathrm{m}^{-2}\right)$ was an order of magnitude greater than that of native species $\left(1.4 \pm 0.4\right.$ stems $\left.\mathrm{m}^{-2}\right)$ within the burned riparian plots sampled.

Post-fire shoot growth

The post-fire phenology of resprouting timing and shoot growth differed significantly between Arundo and native plants (Fig. 3b). Arundo began growing within days after being burned to the ground, whereas resprouts of native woody plants did not appear until January, over 2 months post-fire. The two-way ANOVA of shoot length by plant type and time period revealed a highly significant two-way interaction as the shoot lengths diverged over time (Table 1). Shoot length was 1.7-5.2 times greater (over 2.5 times greater on average) for Arundo than for natives during all months sampled (Fig. 3b).

Arundo shoots grew at a much faster rate than native woody riparian plant species within the first year after fire (Fig. 4). The repeated measures

Table 1 Two-way ANOVA of plant abundance (\% cover), density (stems $\mathrm{m}^{-2}$ ), and shoot length (cm) by factors of plant type (Arundo donax and native plant species) and pre- and post-fire time periods

\begin{tabular}{llll}
\hline Factors and interactions & Plant abundance & Density & Shoot length \\
\hline Plant type & $F_{(1,80)}=59.123 ; P<0.001 * * *$ & $F_{(1,852)}=322.769 ; P<0.001 * * *$ & $F_{(1,3231)}=819.299 ; P<0.001 * * *$ \\
Time period & $F_{(1,80)}=15.166 ; P<0.001 * * *$ & $F_{(5,852)}=1.700 ; P=0.132$ & $F_{(8,3231)}=442.074 ; P<0.001 * * *$ \\
Plant type $\times$ time period & $F_{(1,80)}=0.006 ; P=0.937$ & $F_{(5,852)}=2.850 ; P=0.015^{*}$ & $F_{(8,3231)}=21.295 ; P<0.001 * * *$ \\
$r^{2}$ & 0.626 & 0.287 & 0.591 \\
\hline
\end{tabular}

$*=0.05 \geq P>0.01=$ significant $* *=0.01 \geq P>0.001=$ highly significant $* * *=P \leq 0.001=$ very highly significant 

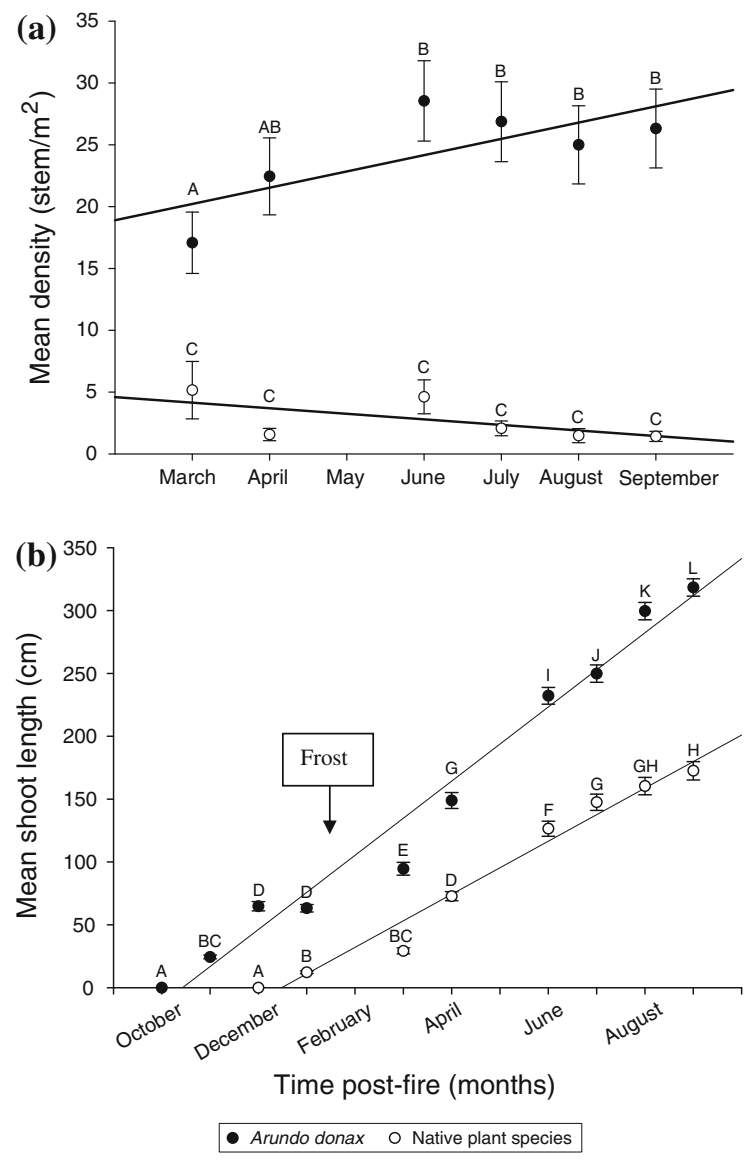

Fig. 3 Mean density (a) and shoot length (b) of Arundo donax versus native woody plants for 1 year after wildfire (October 2003-September 2004). Regression lines illustrate trends over time. Letters denote results of post-hoc hypothesis tests (comparison of means) with significance at $\alpha<0.05$

ANOVA (time post-fire $\times$ plant type) for the shoot elongation rate revealed a significant main effect for time post-fire within subjects due to variation in rates for both Arundo and native plants (Table 2). Arundo emerged immediately after the fire, and the highest Arundo shoot elongation rates were observed in the first two months post-fire. Native woody species did not resprout until January 2004 and grew much more slowly than Arundo. Mean shoot elongation rates of Arundo were significantly higher than those of native woody species except in March and December. A series of heavy frosts occurred in late February 2004 (4 months post-fire) and appeared to have lowered Arundo shoot elongation rates substantially during the March sampling period. In April, shoot elongation rates for both Arundo and native woody species
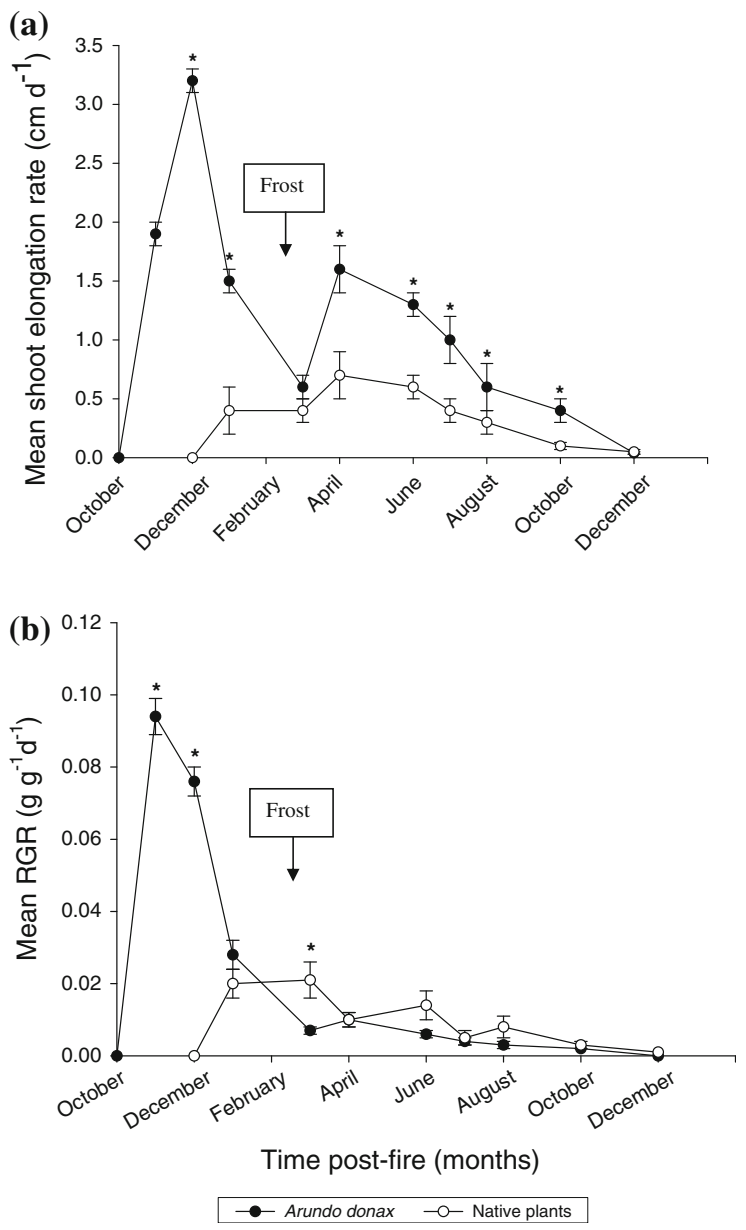

Fig. 4 Mean monthly shoot elongation rates (a) and relative growth rates (b) of Arundo donax compared to native woody plants for 1 year after wildfire (October 2003-September 2004). Asterisks denote significant differences in means between Arundo donax and native plants at each time period based on results of post-hoc hypothesis tests (comparison of means) with significance at $\alpha<0.05$

increased from winter levels, corresponding with warmer spring growing conditions. From April 2004 until the end of the year, elongation rates decreased for all plants, with Arundo maintaining higher rates (up to two times higher) than native species until December 2004.

In the repeated measures ANOVA (time postfire $\times$ plant type), RGR varied significantly by plant type between subjects (individuals) and by time postfire within subjects (Table 2). The mean RGR of Arundo was much greater initially than that of the native woody species (Fig. 4b). Arundo's mean RGR was extremely high $\left(0.094 \pm 0.005 \mathrm{~g} \mathrm{~g}^{-1} \mathrm{day}^{-1}\right)$ 
Table 2 Repeated measures ANOVA with shoot elongation rate $\left(\mathrm{cm} \mathrm{day}^{-1}\right)$ and relative growth rate $\left(\mathrm{RGR}_{\mathrm{g} \mathrm{g}} \mathrm{g}^{-1}\right.$ day $\left.{ }^{-1}\right)$ between time post-fire (months) as dependent variables and plant type (Arundo donax and native plant species) as the independent variable

\begin{tabular}{|c|c|c|c|c|c|c|c|c|}
\hline \multirow[t]{2}{*}{ Factors and interactions } & \multicolumn{4}{|c|}{ Shoot elongation rate } & \multicolumn{4}{|c|}{ RGR } \\
\hline & $d f$ & MS & $F$ & $P$ & $d f$ & MS & $F$ & $P$ \\
\hline \multicolumn{9}{|l|}{ Between subjects } \\
\hline Plant type & 1 & 0.228 & 0.614 & 0.440 & 1 & 0.001 & 16.026 & $<0.001 * * *$ \\
\hline Error & 29 & 0.371 & & & 29 & 0.000 & & \\
\hline \multicolumn{9}{|l|}{ Within subjects } \\
\hline Time post-fire & 6 & 4.559 & 17.071 & $<0.000^{* * *}$ & 6 & 0.001 & 5.983 & $0.001 * * *$ \\
\hline Time post-fire $\times$ plant type & 6 & 0.128 & 0.480 & 0.728 & 6 & 0.000 & 1.796 & 0.158 \\
\hline Error & 174 & 0.267 & & & 174 & 0.000 & & \\
\hline
\end{tabular}

immediately after the fire, whereas native plants did not emerge until the third month after the fire and then grew at a much more moderate rate. Mean RGR of native plants was higher than Arundo only during the spring, 5 months after the fire. While the heavy frosts in February 2004 appeared to curtail Arundo growth, they had little effect on the RGR of native plants. The mean RGR of both Arundo and native plants was very low at the end of the growing season from mid-summer (July) to winter (December).

Post-fire productivity

Approximately 1 year after the fire, Arundo productivity was significantly higher than that of any of the native species $\left[F_{(2,295)}=43.291 ; P<0.001\right]$. Productivity of Arundo $\left(4.83 \pm 0.34 \mathrm{~kg} \mathrm{~m}^{-2}\right.$ year $\left.^{-1}\right)$ was 14 times higher than that of $B$. salicifolia $\left(0.34 \pm 0.06 \mathrm{~kg} \mathrm{~m}^{-2}\right.$ year $\left.^{-1}\right)$ and 24 times higher than that of $S$. laevigata $\left(0.20 \pm 0.08 \mathrm{~kg} \mathrm{~m}^{-2}\right.$ year $\left.^{-1}\right)$ in burned areas. Due to initial low abundance and significant mortality during the year, $S$. exigua, S. lasiolepis, and P. balsamifera subsp. trichocarpa were at such low densities in burned sites that their productivity was undetectable 1 year after the fire.

Soil nutrients

Mean pre- and post-fire soil nutrient levels surrounding Arundo differed significantly from levels found around native plants (Fig. 5; Table 3). Mean soil nutrient levels $\left(\mathrm{NH}_{4}-\mathrm{N}, \mathrm{NO}_{3}-\mathrm{N}\right.$, and $\left.\mathrm{PO}_{4}-\mathrm{P}\right)$ adjacent to Arundo plants increased substantially after the study sites burned, but no significant differences in nutrient concentrations were observed between pre- and post-fire soil adjacent to native woody species. Concentrations of $\mathrm{NH}_{4}-\mathrm{N}$ and $\mathrm{PO}_{4}-\mathrm{P}$ in the soil next to Arundo versus native plant species were significantly higher post-fire.

\section{Discussion}

Several accounts have previously suggested that infestations of Arundo have increased fuel loads as well as fire frequency and intensity along riparian corridors (Robbins et al. 1951; Bell 1997; Scott 1994; D'Antonio 2000). Growing from 4 to $8 \mathrm{~m}$ in height and as fast as $10 \mathrm{~cm} \mathrm{day}^{-1}$ (Perdue 1958; Hickman 1993), Arundo produces abundant flammable biomass that accumulates during the summer and fall months (Rundel 2000). Its ability to recover more rapidly than native plants after fire contributes to its invasion success, but no supporting quantitative evidence for this has been published to date. Several researchers have suggested that fire may increase the ability of Arundo to invade natural riparian systems (Rieger and Kreager 1989; Scott 1994; Bell 1997) and that it may be part of an invasive plant-fire regime cycle, changing riparian ecosystems from primarily flooddefined to fire-defined systems (Bell 1997).

Our study provides the first evidence that wildfire promotes invasion of riparian ecosystems by Arundo. Comparisons of post-fire Arundo and native plant performance demonstrated several physiological and morphological characteristics that give Arundo an advantage over native species after fire.

Three mechanisms-fire-adapted phenology, high growth rate, and growth response to nutrient enrichment-appear to promote the preemption of native 

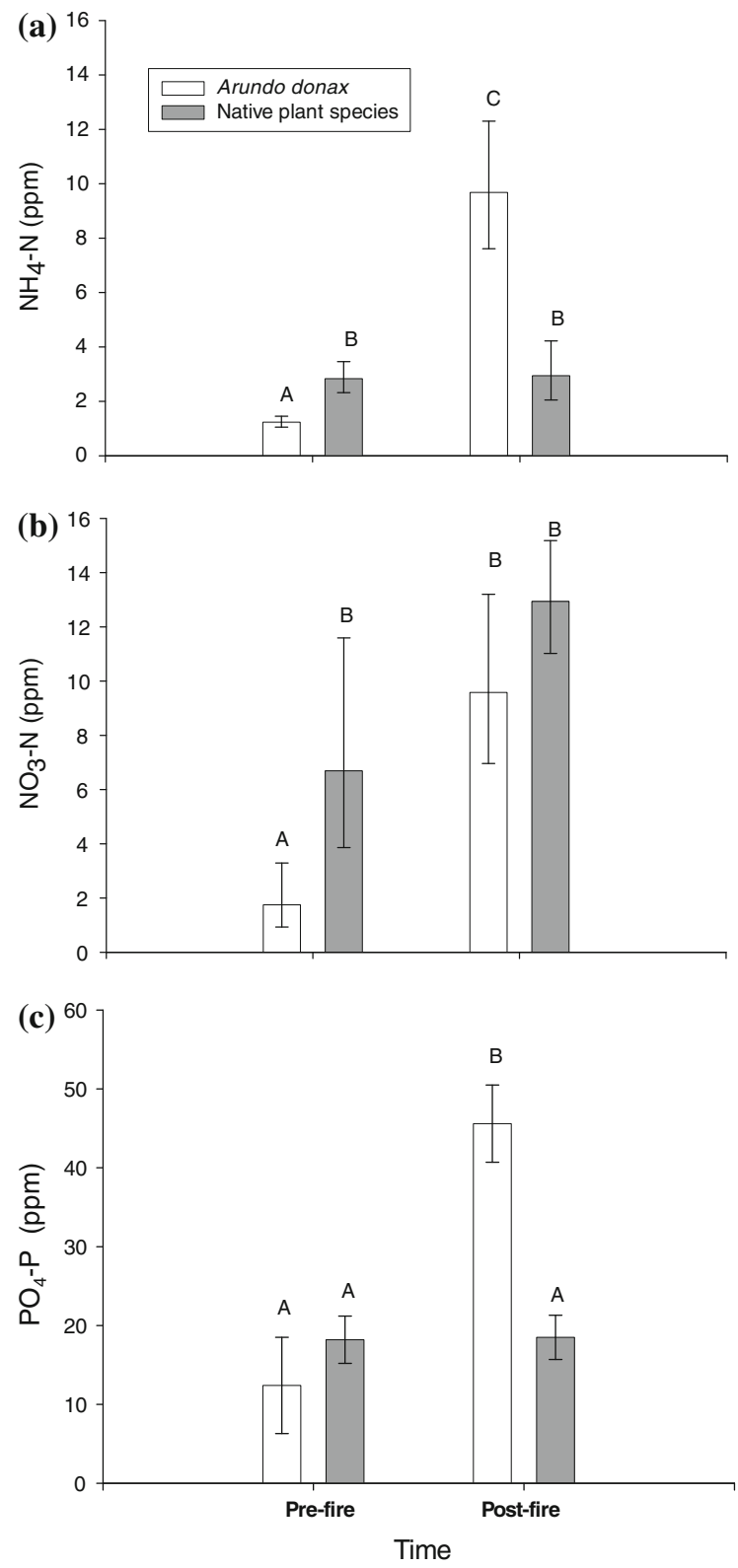

Fig. 5 Pre- and post-fire mean nutrient levels in soil adjacent to Arundo donax compared to soil next to native woody plants. Letters denote results of post-hoc hypothesis tests (comparison of means) with significance at $\alpha<0.05$

woody riparian species by Arundo after fire. Fire stimulated Arundo regrowth almost immediately, as might be expected from a species with large belowground carbohydrate reserves, whereas native woody riparian plant species recovered much more slowly after being burned. The evergreen phenology of Arundo clearly aids this invader in establishing resprouts following late fall or winter fires. Native riparian woody species measured in this study, S. laevigata, S. lasiolepis, S. exigua, P. balsamifera subsp. trichocarpa, and B. salicifolia, are all winter deciduous. Their growth and seedling establishment occur between late winter and early spring, corresponding with declining river flows (Stella et al. 2006) and increased temperatures. Decruyenaere and Holt (2005) found that Arundo exhibited no dormancy during the year in areas with high nitrogen levels, although recruitment of new shoots from rhizomes was higher in the summer than in winter months.

Arundo clearly expanded its dominance in our study area over the first year following the wildfire. It increased in relative abundance by almost $25 \%$ and comprised more than $99 \%$ of the vegetative cover in study sites only a year after fire. The large increase in relative biomass of Arundo 1 year after the fire compared to Salix laevigata and Baccharis salicifolia suggests that abundance of native riparian trees and shrubs might eventually be greatly reduced or excluded completely by Arundo in fire-prone riparian ecosystems. Observations of study sites taken in December 2009 indicate that native plant regeneration after the fire (less than 5\% cover on average) has been greatly reduced due to Arundo dominance. Similar examples of post-fire competitive exclusion of native plant species by invasive grasses have been documented in many ecosystems in which fire is an unnatural or altered process (D'Antonio and Vitousek 1992; D'Antonio 2000; Brooks and Pyke 2001; Keeley 2006). The invasion of riparian forests by saltcedar has also exhibited a substantial effect on the composition and fire regime of riparian woodlands in the southwestern United States (Brothers 1984; Ellis 2000; Glenn and Nagler 2005; Nagler et al. 2005).

Large differences in pre- and post-fire soil nutrient levels post-fire may have stimulated and/or helped maintain high growth rates of Arundo following fire. Precipitation received within a few weeks of the fire mobilized nutrients, making them available for plant uptake. Both field and pot experiments have shown that Arundo responds positively to nutrient enrichment under non-burn conditions and may enhance competition with native plants under some conditions (Coffman 2007; Quinn et al. 2007). Levels of ammonia-N and orthophosphate in the soil surrounding Arundo were much higher in riparian study sites 
Table 3 Two-way ANOVA of soil nutrients [ammonia-N $\left(\mathrm{NH}_{4}-\mathrm{N}\right)$, nitrate-N $\left(\mathrm{NO}_{3}-\mathrm{N}\right)$, and orthophosphate $\left.\left(\mathrm{PO}_{4}-\mathrm{P}\right)\right]$ by factors of plant type (Arundo donax and native plant species) and pre- and post-fire time periods

\begin{tabular}{llll}
\hline Factors and interactions & $\mathrm{NH}_{4}-\mathrm{N}(\mathrm{ppm})^{\mathrm{a}}$ & $\mathrm{NO}_{3}-\mathrm{N}(\mathrm{ppm})^{\mathrm{a}}$ & $\mathrm{PO}_{4}-\mathrm{P}(\mathrm{ppm})$ \\
\hline Plant type & $F_{(1,23)}=1.120 ; P=0.301$ & $F_{(1,23)}=2.160 ; P=0.155$ & $F_{(1,23)}=4.511 ; P=0.045^{*}$ \\
Time period & $F_{(1,23)}=12.737 ; P=0.002^{* *}$ & $F_{(1,23)}=5.037 ; P=0.035^{*}$ & $F_{(1,23)}=7.044 ; P=0.014^{*}$ \\
Plant type $\times$ time period & $F_{(1,23)}=12.753 ; P=0.002^{* *}$ & $F_{(1,23)}=0.967 ; P=0.336$ & $F_{(1,23)}=7.281 ; P=0.013^{*}$ \\
Silt + clay $^{\mathrm{b}}$ & $F_{(1,23)}=5.245 ; P=0.032^{*}$ & $F_{(1,23)}=0.893 ; P=0.354$ & $F_{(1,23)}=3.240 ; P=0.085$ \\
$r^{2}$ & 0.690 & 0.322 & 0.607 \\
\hline
\end{tabular}

${ }^{a}$ Data $\ln$ transformed

b Soil grain size (\% silt + clay) was used as a covariate

after the fire, whereas soil nutrient levels adjacent to native plants did not change. Higher post-fire soil nutrient levels found next to Arundo versus native plants were likely due to quality and quantity of fuel (vegetation) burned, fire intensity, and resulting ash deposited (Debano and Conrad 1978).

Riparian ecosystems invaded by Arundo adjacent to fire-prone shrublands in southern California appear to be on a trajectory toward a potential invasive plant-fire regime cycle (Brooks et al. 2004). Introduction of a tall clonal grass species such as Arundo into this riparian ecosystem has altered fuel types and loads (Scott 1994; Brooks et al. 2004). Decreased moisture content and increased surface-to-volume ratio of Arundo versus native vegetation may lead to altered or increased fire susceptibility or increased probability of ignition in these systems. Addition of this fuel to the riparian ecosystem has increased vertical continuity (i.e., the structure of fuel allows fire to spread from surface to crowns of shrubs and trees). Due to its tall growth form, infestations of Arundo mixed with native species may spread fire vertically into the canopy of riparian trees.

The October 2003 Simi/Verdale wildfire provides an excellent example of the invasive plant-fire regime cycle that Arundo invasion has created. The wildfire reached the Santa Clara River from the north, crossed the broad riverbed through large stands of Arundo (one of our permanent study sites), then burned through thousands of hectares of native shrublands and alien grasslands before again entering extensive riparian woodlands intermixed with Arundo to the west along the river (Fig. 1).

The results of this study have important implications for Arundo invasion in river systems in other regions of the world. Removal of Arundo from riparian ecosystems adjacent to fire-prone shrublands in arid climates should be a key management priority.
Negative effects on other ecosystem functions, such as wildlife habitat reduction (Knick et al. 2005), generally follow fire regime changes (Brooks et al. 2004) and associated plant invasions (Herrera and Dudley 2003; Kisner 2004). The invasion of Arundo on riparian terraces adjacent to communities or agricultural fields and structures pose an increased risk of fire to people and property.

Post-fire removal of Arundo when aboveground biomass is still low helps to reduce future fire risk. However, time of year is critical to selection and success of appropriate removal techniques, and diligent maintenance is required to completely remove Arundo (Spencer et al. 2005; Coffman 2007). Active planting of removal areas with a diverse composition of native species may be required to prevent reinvasion by Arundo or other exotic species due to enhanced nutrient levels and openings in the canopy (Quinn and Holt 2008) in post-fire riparian ecosystems.

Acknowlegements We gratefully acknowledge the field and laboratory efforts of T. Easley, M. Burns, D. Quick, C. Bowman, H. Haase, R. Kumar, G. Barboza, S. Abichandani, J. Arevalo, N. Wenner, B. Huntington, D. Reineman, A. Duffey, M. Tollett, L. Barlow, H. Hedrick, B. Hedrick, E. J. Remson, C. Bell, G. N. Coffman, and M. L. Coffman. We thank W. Sears, S. Araya, R. Elisha, and S. Lewis for GPS and GIS mapping assistance. Many thanks to T. Dudley, A. Lambert, B. Orr, and P. Brand for manuscript review and discussion. Research was supported by funds from the University of California Center for Water Resources and the California State Coastal Conservancy. The authors are also grateful to two anonymous referees for points that improved the manuscript.

Open Access This article is distributed under the terms of the Creative Commons Attribution Noncommercial License which permits any noncommercial use, distribution, and reproduction in any medium, provided the original author(s) and source are credited. 


\section{References}

Bell GP (1997) Ecology and management of Arundo donax, and approaches to riparian habitat restoration in southern California. In: Brock J, Wade M, Pysek P, Green D (eds) Plant invasions: studies from North America and Europe. Backhuys, Leiden, Netherlands, pp 103-113

Bond WJ, Keeley JE (2005) Fire as a global 'herbivore': the ecology and evolution of flammable ecosystems. Trends Ecol Evol 20:387-394

Brooks ML (2002) Peak fire temperatures and effects on annual plants in the Mojave Desert. Ecol Appl 12:1088-1102

Brooks ML, Pyke DA (2001) Invasive plants and fire in the deserts of North America. In: Galley KEM, Wilson TP (eds) Proceedings of the invasive plant workshop: the role of fire in the control and spread of invasive species. Tall Timbers Research Station, Tallahassee, Florida, pp 1-14

Brooks ML, D'Antonio CM, Richardson DM, Grace JB, Keeley JE, DiTomaso JM, Hobbs RJ, Pellant M, Pyke D (2004) Effects of invasive plants on fire regimes. Bioscience 54:677-688

Brothers TS (1984) Historical vegetation change in the Owens River riparian woodland. In: Warner RE, Hendrix KM (eds) California riparian systems: ecology, conservation, and productive management. University of California Press, Berkeley, California, pp 75-84

Coffman GC (2007) Factors influencing invasion of giant reed (Arundo donax) in riparian ecosystems of Mediterraneantype climate regions. Dissertation, University of California, Los Angeles

D'Antonio CM (2000) Fire, plant invasions, and global changes. In: Mooney HA, Hobbs RJ (eds) Invasive species in a changing world. Island Press, Washington, DC, pp 65-93

D'Antonio CM, Vitousek PM (1992) Biological invasions by exotic grasses, the grass/fire cycle, and global change. Annu Rev Ecol Syst 23:63-87

Debano LF, Conrad CE (1978) The effect of fire on nutrients in a chaparral ecosystem. Ecology 59:489-497

Decruyenaere JG, Holt JS (2005) Ramet demography of a clonal invader, Arundo donax (Poaceae), in Southern California. Plant Soil 277:41-52

Dudley T (1998) Exotic plant invasions in California riparian areas and wetlands. Fremontia 26:24-29

Dudley TL, DeLoach CJ, Lovich JE, Carruthers RI (2000) Saltcedar invasion of Western riparian areas: impacts and new prospects for control. In: McCabe RE, Loos SE (eds) Transactions, 65th No. American wildlife and natural resource conference, March 2000. Rosemont, Illinois. Wildlife Management Institute, Washington, DC, pp 345-381

Duncan KW (1997) A case study in Tamarix ramosissima control: Spring Lake, New Mexico. In: Brock JH, Wade M, Pyšek P, Green D (eds) Plant invasions: studies from North America and Europe. Backhuys Publishers, Leiden, pp 115-121

Ellis LM (2000) Short-term response of woody plants to fire in a Rio Grande riparian forest, Central New Mexico, USA. Biol Conserv 97:159-170

Else JA (1996) Post-flood establishment of native woody species and an exotic, Arundo donax, in a Southern
California riparian system. Thesis, San Diego State University, San Diego

Gaffney KA (2002) Invasive plants in riparian corridors: distribution, control methods and plant community effects. Thesis, Sonoma State University, Rohnert Park, California

Glenn E, Nagler P (2005) Comparative ecophysiology of saltcedar and native trees in western US riparian zones. $\mathrm{J}$ Arid Environ 61:419-446

Herrera AM, Dudley TL (2003) Reduction of riparian arthropod abundance and diversity as a consequence of giant reed (Arundo donax) invasion. Biol Invasions 5:167-177

Hickman JC (1993) The Jepson manual: higher plants of California. University of California Press, Berkeley, California

Johnson M, Dudley T, Burns C (2006) Seed production in Arundo donax? Cal-IPC News. Fall, pp 12-13

Keeley JE (1982) Distribution of lightning and man-caused wildfire in California. In: Conrad CE, Oechel W (eds) USDA Forest Service, Pacific Southwest Forest and Range Experiment Station, General Technical Report PSW-58, Proceedings of the symposium on dynamics and management of Mediterreanean-type ecosystems, pp 431-437

Keeley JE (2004) Invasive plants and fire management in California Mediterranean-climate ecosystems. In: Arianoutsou M, Papanastasis VP (eds) 10th International Conference on Mediterranean Climate Ecosystems (MEDECOS; full text on cd). Mill Press, Rhodes, p 128

Keeley JE (2006) Fire management impacts on invasive plants in the western US. Conserv Biol 20:375-384

Keeley JE (2009) Fire intensity, fire severity and burn severity: a brief review and suggested usage. Int $\mathrm{J}$ Wildland Fire 18:116-126

Keeley JE, Fotheringham CJ (2001) Historic fire regime in Southern California shrublands. Conserv Biol 15:15361548

Keeley JE, Fotheringham CJ (2005) Lessons learned from the wildfires of October 2003. In: Halsey RW (ed) Fire, chaparral, and survival in southern California. Sunbelt Publications, San Diego, pp 112-122

Keeley JE, Fotheringham CJ, Morais M (1999) Reexamining fire suppression impacts on brushland fire regimes. Science 284:1829-1931

Kisner DA (2004) The effect of giant reed (Arundo donax) on the southern California riparian bird community. Thesis, San Diego State University, San Diego

Knick ST, Holmes AL, Miller RF (2005) The role of fire in structuring sagebrush habitats and bird communities. Stud Avian Biol 30:63-75

Nagler PL, Hinojosa-Huerta O, Glenn E, Garcia-Hernandez J, Romo R, Curtis C, Huete A, Nelson S (2005) Regeneration of native trees in the presence of saltcedar: results of an inadvertent, 20 year pulse-flood experiment in the Colorado River Delta, Mexico. Conserv Biol 19:1842-1852

Naveh Z (1975) The evolutionary significance of fire in the Mediterranean region. Vegetatio 29:199-208

Perdue RE (1958) Arundo donax - source of musical reeds and industrial cellulose. Econ Bot 12:157-172

Quinn LD, Holt JS (2008) Ecological correlates of invasion by Arundo donax in three southern California riparian habitats. Biol Invasions 10:591-601 
Quinn LD, Rauterkus MA, Holt JS (2007) Effects of nitrogen enrichment and competition on growth and spread of giant reed (Arundo donax). Weed Sci 55:319-326

Rieger JP, Kreager DA (1989) Giant reed (Arundo donax): a climax community of the riparian zone. In: Abell DL (ed) USDA Forest Service Gen Tech Rep PSW-110. Proceedings of the California riparian systems conference: protection, management, and restoration for the $1990 \mathrm{~s}$. Berkeley, California, pp 222-225

Robbins WW, Bellue MK, Ball WS (1951) Weeds of California. Department of Agriculture, Sacramento, California

Rundel PW (2000) Alien species in the flora and vegetation of the Santa Monica Mountains, CA: patterns, processes, and management implications. In: Keeley JE, Baer-Keeley M, Fotheringham CJ (eds), 2nd interface between ecology and land development in California. US Geological Survey Open-File Report 00-62, pp 145-152

Scott G (1994) Fire threat from Arundo donax. In: Jackson NE, Frandsen P, Douthit S (eds) Arundo donax workshop proceedings. Ontario, California, November 19, 1993. University of California Cooperative Extension, Imperial County, pp 17-18

Sharifi MR, Nilsen ET, Rundel PW (1982) Biomass and net primary production of Prosopis glandulosa (Fabaceae) in the Sonoran Desert of California. Am J Bot 69:760-767

Sheldrick BH, Wang C (1993) Particle-size distribution. In: Carter MR (ed) Soil sampling and methods of analysis, Canadian Society of Soil Science. Lewis Publishers, Ann Arbor, pp 499-511
Spencer DF, Ksander GG, Whitehand LD (2005) Spatial and temporal variation in RGR and leaf quality of a clonal riparian plant: Arundo donax. Aquat Bot 81:27-36

Spencer DF, Liow PS, Chan WK, Ksander GG, Getsinger KD (2006) Estimating Arundo donax shoot biomass. Aquat Bot 84:272-276

Stella JC, Battles JJ, Orr BK, McBride JR (2006) Synchrony of seed dispersal hydrology and local climate in a semi-arid river reach in California. Ecosyst 9:1200-1214

Stillwater Sciences, URS (2007) Riparian vegetation mapping and preliminary classification for the lower Santa Clara River and major tributaries, Ventura County, California. Prepared for California State Coastal Conservancy and Santa Clara River Trustee Council

Sugihara NG, van Wagtendonk JW, Shaffer KE, Fites-Kaufman J, Thode AE (2006) Fire in California's ecosystems. University of California Press, Berkeley, California

Systat Software, Inc. (2000) SYSTAT Version 10. San Jose, California

Whittaker RH (1965) Branch dimensions and estimation of branch production. Ecology 46:365-370

Whittaker RH, Marks PL (1975) Methods of assessing terrestrial productivity. In: Lieth $\mathrm{H}$, Whittaker RH (eds) Primary productivity of the biosphere. Springer, New York, pp 55-118 